EISSN: $2706-7947 \quad$ ISSN: 2077- 4613

DOI: $10.36632 /$ mejas/2021.11.1.29

Journal homepage: www.curresweb.com

Pages: 360-367

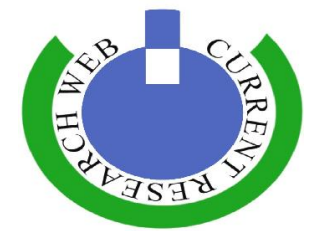

\title{
Application of Trichoderma Spp. in Controlling Orobanche Ramosa Parasitism in Chamomile
}

\author{
Mahmoud A.T. El-Dabaa' ${ }^{1}$, Karima H. E. Haggag² and Ragab A. El-Mergawi ${ }^{1}$ \\ ${ }^{1}$ Botany Department, National Research Centre, Dokki, Cairo, Egypt \\ ${ }^{2}$ Pest Rearing Department, Central Agricultural Pesticides Laboratory, Agricultural Research Centre, \\ Dokki, Giza, Egypt.
}

\author{
Received: 18 January $2021 \quad$ Accepted: 20 March $2021 \quad$ Published: 30 March 2021
}

\begin{abstract}
Biological control could play a role in the management of Orobanche parasitism in plant production. Two greenhouse experiments were conducted to evaluate the effect of three Trichoderma spp.including $T$. hamatum, $T$. viride and $T$. harzianum on controlling $O$. ramose parasite in chamomile plant .Soil treatment with Trichoderma (at $3.6 \times 10^{8}$ propagules $\mathrm{g}^{-1}$ ) was effective in reducing infection with $O$. ramose by delaying in Orobanche attachments and reducing number and growth of tubercles. $T$. hamatum and T. viride completely protected chamomile plants against Orobanche infestation until 3 months after transplanting. Fungi treatments caused more than $75 \%$ reduction in number of $O$. ramosa attachments, fresh and dry weights of tubercles. Moreover, Trichoderma treatments improved chamomile growth, where the treatments increased fresh and dry plant biomass between $59-90 \%$ and 67.6-112.2\%, respectively compared with untreated plants. Among the three applied fungi, $T$. viride produced the most enhancement effects on chamomile growth. Results revealed that the application of tested Trichoderma spp. could play an important effect in controlling $O$. ramosa parasitism in chamomile as a natural bio-herbicide as well as enhancing the growth parameters of chamomile.
\end{abstract}

Keywords: Matricaria chamomilla L., holoparasite, fungi, bio-herbicide

\section{Introduction}

Chamomile plant (Matricaria chamomilla L.) is grown in Egypt and it is used for medical and industrial purposes. Orobanche species are serious parasitic weeds causing considerable losses in many major crops including chamomile. Orobanche attack plant roots of many agricultural crops, i.e. cabbages, potato, tomato, melon, watermelon and other crops in the Mediterranean region (Amsellem et al., 2001; Hassan et al., 2004; Nawar and Sahab, 2011).

Orobanche (broomrape) is widespread on winter crops as well as recently become one of the most serious problems in Egyptian agricultural productions (Abdel-Kader and El-Mougy, 2007). No single effective and economical method for management of Orobanche is available, where alternative methods viz. preventive, physical, chemical, agronomic, biological, crop resistance and integrated methods are needed to manage this parasite (Habimana et al., 2014; Punia, 2014). Applications of biological agents become play an important role for controlling plant pathogens as well as weeds in fields. Because of application of herbicides has many problems such as contamination of groundwater, destruction to the non-target species and induction of resistance against herbicides in numbers of weed species as well as other control methods become more unsuitable where the weeds are widespread. Therefore, the researchers moved toward biological control as an alternative approaches for managing of weeds (Mustafa et al., 2019).

The capability of Trichoderma spp. i.e. T. harzianum and T. viride for controlling Orobanche spp. in peas, faba bean and tomatoes under field conditions was observed by Abdel-Kader and El-Mougy (2009). They found that soil treatment with these fungi, as bio-control agents, was effective in reducing broomrapes infection and increasing yield of plants. Also, Abdel-Kader and El-Mougy (2007) found

Corresponding Author: Mahmoud A.T. El-Dabaa, Botany Department, National Research Centre, Dokki, Cairo, Egypt. E-mail: eldabaam@yahoo.com 
that application of $T$. harzianum and $T$. viride, followed by foliar spray with glyphosate herbicide was the most appropriate treatment for controlling $O$. ramosa in tomato plants under field conditions. The treatment significantly reduced the incidence and intensity of broomrape branches as well as increased the tomato yield in comparison with the individual treatment. It is revealed that this treatment could develop because of an effective, applicable and cost-effective method acceptable for controlling $O$. ramosa in tomatoes. Application of $T$. harzianum and the commercial product (Plant Guard, $T$. harzianum) reduced number of Orobanche shoots in comparison with the control. T. viride and $T$. hamatum were found to be effective in reducing the Orobanche shoot numbers (Nawar and Sahab, 2011). Field application of $T$. harzianum alone or in combination with Bacillus megatherium var. phosphaticum significantly reduced number of $O$. crenata emergence and significantly increased faba bean biomass such as pod/plant, grain yield and 100 seed weight, compared to the controls (Yahia et al., 2018). T. harzianum, T. viride and T. vierns could protect faba bean plants against $O$. crenata infection, where the treatments reduced number, fresh weight and dry weight of juveniles. All Trichoderma spp. treatments highly increased the plant growth parameters. It is clear that application of Trichoderma spp. could play an important role in controlling broomrape in faba bean as a natural bio-herbicide (El-Dabaa and Abd-El-Khair, 2020).

Therefore, this study was conducted during two successive seasons to determine the effect of orobanche infestation on chamomile growth and the efficacy of Trichoderma spp. i.e. T. hamatum, $T$. harzianum and $T$. viride on controlling $O$. ramose infestation and improving chamomile growth.

\section{Materials and Methods}

\subsection{Plant materials}

Seeds of chamomile (Matricaria chamomilla) were obtained from Ministry of Agriculture, Giza, Egypt. Seeds were firstly sown in a seedling tray $(50 \times 90 \mathrm{~cm}$ diameter).Then, after 30 days of sowing; seedlings were transplanted in experimental pots. Seeds of O. ramosa or O. crenata were collected from an infested field and stored in the dark at $25^{\circ} \mathrm{C}$ until use. Three of Trichoderma spp., i.e. T. hamatum, T. harzianum and T. viride, were obtained from Pest Rearing Department, Central Agricultural Pesticides Laboratory, Agricultural Research Centre, Dokki, Giza, Egypt (El-Dabaa and Abd-El-Khair, 2020).

\subsection{Preparation of Trichoderma spp. inocula}

For preparation of Trichoderma spp. propagules; each of T. hamatum or T. harzianum or T. viride was separately prepared using Sorghum - Sand - Water $(2: 2: 1, \mathrm{~V}: \mathrm{V}: \mathrm{V})$ medium. The sterilized medium was individually inoculated by each fungus, using fungal disc (1-cm diameter) obtained from 7-day-old culture. The inoculated medium was incubated at $30 \pm 2{ }^{\circ} \mathrm{C}$ for 15 days. The resulting fungal inocula were applied in pots experiment. Trichoderma inocula were adjusted, at $3.6 \times 10^{8}$ propagules/gram, by using a haemocytometer slide. Then a mixture of each Trichoderma propagules was applied separately (El-Nagdi et al., 2019).

\subsection{Greenhouse experiments}

Two pot experiments were carried out during two successive winter seasons of 2016/2017 and 2017/2018 in the greenhouse, Botany Department, National Research Center at Dokki, Cairo, Egypt. The first experiment was conducted in the $1^{\text {st }}$ season to examine the capability of $O$. crenata and $O$. ramosa to attack chamomile plants and their effects on chamomile growth parameters under greenhouse condition during 4 months after transplanting (MAT). Plastic pots (30-cm diameter), containing $5 \mathrm{~kg}$ of a sterilized mixture of loamy soil ( $48.4 \%$ sand, $41.1 \%$ silt, and $10.5 \%$ clay; $\mathrm{pH} 8.0)$ were arranged according to a completely randomized design on a bench under greenhouse conditions. The pots were separately artificially infested with each Orobanche sp. seeds at the rate of $5 \%(\mathrm{~W} / \mathrm{W})$ at $5 \mathrm{~cm}$ of the soil surface. The soil pots free of Orobanche sp. contamination were applied as the control. Then, four chamomile seedlings (30 days-old) were transplanted in each pot. Four pots were applied as replicates for each treatment as well as the control. The pots maintained at $25 \pm 5^{\circ} \mathrm{C}$ and the plants were irrigated and fertilized regularly. The numbers, fresh weight and dry weight of the emerged Orobanche were recorded at 1, 2, 3 and 4 MAT. The growth parameters of chamomile plants as plant height $(\mathrm{cm})$, plant 
fresh and dry weights (g), as well as fresh and dry weights of roots $(\mathrm{g})$ were recorded during examined periods.

Second experiment was conducted in the second season to examine the efficacy of Trichoderma spp. for controlling $O$. ramosa in chamomile plants. Twenty plastic pots (30-cm diameter), containing $5 \mathrm{~kg}$ of a sterilized mixture of clay soil were arranged according to a completely randomized design on a bench under greenhouse conditions. The pots were separately artificially infested with $O$. ramosa seeds bank at the rate of $5 \%(\mathrm{~W} / \mathrm{W})$ at $5 \mathrm{~cm}$ of the soil surface. Then, Trichoderma spp. treatments were applied at a rate of $5 \%(\mathrm{w}: \mathrm{w})$ before one week of transplanting and then all pots were watered. The soil infested with $O$. ramosa as well as soil free of $O$. ramosa contamination were applied as the controls. The treatments were as follows; $T$. hamatum $+O$. ramosa; $T$. harzianum $+O$. ramosa; $T$. viride $+O$. ramosa; $O$. ramosa alone and untreated control and then all pots were watered. Then, four chamomile seedlings (30 days-old) were transplanted in each pot. The pots maintained at $25 \pm 5^{\circ} \mathrm{C}$ and the plants were irrigated and fertilized regularly. Effects of Trichoderma spp. on numbers, fresh and dry weights of the emerged Orobanche were recorded at 1, 2, 3 and 4 MAT. The growth parameters of chamomile plants as plant height $(\mathrm{cm})$, plant fresh weight $(\mathrm{g})$, plant dry weight $(\mathrm{g})$, root fresh and dry weights $(\mathrm{g})$ were recorded over4 MAT.

\subsection{Statistical analysis}

The obtained data in two pot experiments were subjected to analysis of variance using Computer Statistical Package User Manual Version 3.03, Barkley Co., USA and mean values of treatments were compared by Duncan's multiple range test at $\mathrm{P}=0.05$ level of significance (Snedecor and Cochran, 1999).

\section{Results and Discussion}

\subsection{Sensitivity of chamomile plant to $O$. crenata and $O$. ramosa infestation}

Capability of $O$. crenata and $O$. ramosa to attack chamomile plants was studied under greenhouse condition during 4 months after transplanting (MAT). The results revealed that chamomile plant is susceptible to $O$. ramosa, whereas it maintained complete resistance to $O$. crenata infestation (Table 1). Number of $O$. ramosa attachments developed during the examined period and constituted 10.8 per plant at the end of examined period (4 MAT). Also, fresh and dry weights of $O$. ramose plants were increased throughout the examined period and reached 28.1 and $4.53 \mathrm{~g}$ per plant, respectively, at 4 MAT. These results are in agreements with the obtained results by Habimana et al. (2014) and Punia (2014). They reported that Orobanche spp. could parasite on leguminous, oilseeds, solanaceous, cruciferous and medicinal plants. Meanwhile, Nawar and Sahab (2011) reported that O. ramosa attacks chamomile herbs, through their excreta (Habimana et al., 2014).

\subsection{Effect of $O$. ramosa infestation on chamomile growth}

Growth parameters of infested and non-infested chamomile plants were measured during 4 MAT. Chamomile growth was affected negatively with $O$. ramosa infestation at all examined times (Table 2). Various growth parameters of infested plants exhibited significant decreases in comparison with noninfested plants. Height, fresh and dry weight of infested plants was in the range 14.8- $61.8 \mathrm{~cm}, 39.9-$ $88.0 \mathrm{~g}$ and $4.5-17.7 \mathrm{~g}$, respectively against $17.5-69.3 \mathrm{~cm}, 57.9-125.1 \mathrm{~g}$ and 6.7-27.6 g, respectively for non-infested plants. At the end of examined period (4 MAT), infestation caused great decreases in plant height (10.8\%), fresh weight (29.7\%) and dry weight (35.9\%). Also, O. ramosa infestation produced a pronounced decrease in root growth, over the examined period. Since, values of root fresh and dry weights of infested plants ranged between 4.8-8.7 and 0.3-2.3 g, respectively against 5.0-12.9 and 0.9$3.4 \mathrm{~g}$ for non-infested plants, respectively. At the end of examined period (4 MAT), O. ramose reduced fresh and dry biomass of root with about $32 \%$. Many investigators recorded tremendous damage during growth stages of host plants as affected with $O$. ramosa infestation (Hassan et al., 2004; Al-Wakeel et al., 2013; Habimana et al., 2014). Due to their achlorophyllous nature, Orobancheis constrained to obtain their nutritional resources from the host (Westwood, 2000). The damage induced in the host plant by Orobanche parasitism differs for each Orobanche-host association (Fernández-Aparicio et al., 2016). In some plants, the biomass loss equals to that accumulated by the parasite indicating that 
damage in the plant is directly attributed to the parasitic sink activity (Hibberd et al., 1998). However, in other Orobanche-host associations the damage induced through negative effects on the plant photosynthetic machinery and hormonal balance (Mauromicale et al., 2008).

Table 1: Growth of O.ramosa and O.crenata parasites on chamomile plant under greenhouse conditions

\begin{tabular}{ccccccc}
\multicolumn{2}{c}{$\left(1^{\text {st }}\right.$ season $)$} \\
\hline \multirow{2}{*}{ MAT } & \multicolumn{2}{c}{ Number of emerged spike } & \multicolumn{2}{c}{ Fresh weight $(\mathrm{g})$} & \multicolumn{2}{c}{ Dry weight $(\mathrm{g})$} \\
\cline { 2 - 7 } & O. ramosa & O. crenata & O. ramosa & O. crenata & O. ramosa & O. crenata \\
\hline $\mathbf{1}$ & $1.5^{\mathrm{a}}$ & $0.0^{\mathrm{b}}$ & $0.8^{\mathrm{a}}$ & $0.0^{\mathrm{b}}$ & $0.01^{\mathrm{a}}$ & $0.0^{\mathrm{b}}$ \\
\hline $\mathbf{2}$ & $6.8^{\mathrm{b}}$ & $0.0^{\mathrm{b}}$ & $5.2^{\mathrm{b}}$ & $0.0^{\mathrm{b}}$ & $0.93^{\mathrm{b}}$ & $0.0^{\mathrm{b}}$ \\
\hline $\mathbf{3}$ & $9.5^{\mathrm{c}}$ & $0.0^{\mathrm{b}}$ & $26.6^{\mathrm{c}}$ & $0.0^{\mathrm{b}}$ & $3.80^{\mathrm{c}}$ & $0.0^{\mathrm{b}}$ \\
\hline $\mathbf{4}$ & $10.8^{\mathrm{d}}$ & $0.0^{\mathrm{b}}$ & $28.1^{\mathrm{d}}$ & $0.0^{\mathrm{b}}$ & $4.53^{\mathrm{d}}$ & $0.0^{\mathrm{b}}$
\end{tabular}

Values are given as means of three replicates. Means with the same letters in a row are not significantly different at $\mathrm{P}<0.05$.

Table 2: Effect of $O$. ramosa infestation on chamomile growth during four months after transplanting (MAT) $\left(1^{\text {st }}\right.$ season $)$

\begin{tabular}{|c|c|c|c|c|c|c|c|c|c|c|c|c|}
\hline \multicolumn{13}{|c|}{ Plant growth } \\
\hline Parameter & & Heigh & (cm) & & & Fresh w & ight (g) & & & Dry w & ight (g) & \\
\hline MAT & 1 & 2 & 3 & 4 & 1 & 2 & 3 & 4 & 1 & 2 & 3 & 4 \\
\hline $\begin{array}{l}\text { Infested } \\
\text { plants }\end{array}$ & $14.8^{\mathrm{a}}$ & $32.0^{\mathrm{b}}$ & $55.3^{c}$ & $61.8^{\mathrm{d}}$ & $39.9^{\mathrm{a}}$ & $43.1^{b}$ & $64.7^{\mathrm{c}}$ & $88.0^{\mathrm{d}}$ & $4.5^{\mathrm{a}}$ & $14.0^{\mathrm{b}}$ & $16.0^{\mathrm{c}}$ & $17.7^{\mathrm{d}}$ \\
\hline $\begin{array}{l}\text { non- } \\
\text { infested } \\
\text { plants }\end{array}$ & $17.5^{\mathrm{a}}$ & $34.8^{\mathrm{a}}$ & $57.5^{\mathrm{a}}$ & $69.3^{\mathrm{a}}$ & $57.9^{\mathrm{a}}$ & $74.5^{\mathrm{a}}$ & $103.4^{\mathrm{a}}$ & $125.1^{\mathrm{a}}$ & $6.7^{\mathrm{a}}$ & $18.2^{\mathrm{a}}$ & $20.5^{\mathrm{a}}$ & $27.6^{\mathrm{a}}$ \\
\hline
\end{tabular}

\begin{tabular}{lcccccccc}
\hline & \multicolumn{3}{c}{ Root growth } \\
\hline Parameter & \multicolumn{4}{c}{ Fresh weight (g) } & \multicolumn{3}{c}{ Dry weight (g) } \\
\hline MAT & $\mathbf{1}$ & $\mathbf{2}$ & $\mathbf{3}$ & $\mathbf{4}$ & $\mathbf{1}$ & $\mathbf{2}$ & $\mathbf{3}$ & $\mathbf{4}$ \\
\hline Infested plants & $4.8^{\mathrm{a}}$ & $6.5^{\mathrm{b}}$ & $8.5^{\mathrm{c}}$ & $8.7^{\mathrm{c}}$ & $0.3^{\mathrm{a}}$ & $1.3^{\mathrm{b}}$ & $1.8^{\mathrm{c}}$ & $2.3^{\mathrm{d}}$ \\
\hline non-infested plants & $5.0^{\mathrm{a}}$ & $8.2^{\mathrm{a}}$ & $9.1^{\mathrm{c}}$ & $12.9^{\mathrm{d}}$ & $0.9^{\mathrm{a}}$ & $1.8^{\mathrm{b}}$ & $2.2^{\mathrm{c}}$ & $3.4^{\mathrm{d}}$ \\
\hline
\end{tabular}

Values are given as means of three replicates. Means with the same letters in a column are not significantly differentat $\mathrm{P}<0.05$.

\subsection{Effect of Trichoderma spp. on controlling $O$. ramosa parasitism}

The results showed that application of Trichoderma spp. capable to control $O$. ramose parasitism in chamomile plants by delaying attachment time and reducing the number and growth of emerged spikes (Table 3). The most effective Trichoderma spp. on $O$. ramosa parasitism was $T$. hamatum followed with $T$. viride. These two species completely protected chamomile plants against Orobanche infestation until 3 MAT. Also, at $4^{\text {th }}$ month, T. hamatum and T. viride treatments caused great reduction in number of $O$. ramosa attachments $(95.2 \%$ and $75.8 \%$, respectively) and produced more than $90 \%$ reduction in fresh and dry weights of tubercles. Also, T. harzianum prevented $O$. ramosa attachment in chamomile plants for one month. During the last three times points (2-4 MAT) T. harzianum caused great decreases in number attachments (between 77.8-81.8 \%), fresh weight (48.9-90.6\%) and dry weight of tubercles (42.9-85.7\%). In line of the obtained results, Boari and Vurro (2014) found that fungi can apply as bio-control agents against $O$. ramosa. Hence, Trichoderma extensively applied in agriculture worldwide for crop protection due to their antimicrobial activities in suppressing a broad range of phyto-pathogens (Harman, 2006).T. harzianum and T. viride produced potential herbicidal metabolites which could inhibit seeds germination or shoot and root growths of some herbs seedlings (Kuang et al., 2016). Many investigators reported that Trichoderma spp. could play an important role in controlling $O$. crenata in pea and faba bean fields as a natural bio-herbicide (Abdel-Kader and ElMougy, 2002; El-Dabaa and Abd-El-Khair, 2020). Also, Hyder et al. (2017) found that application of Trichoderma spp. reduced the number of Orobanche shoots. They suggested that presence of Trichoderma in the rhizosphere could colonize the plant roots, receives nutrients from root exudates 
and exchange for plant protection against biotic and abiotic stresses. Trichoderma secretes the low molecular weight compounds, peptides and proteins as well as it have antagonistic mechanisms include mycoparasitism, antibiotic production and competition for nutrients. Moreover, Trichoderma can exert an indirect control against pathogens through the induced systemic response (ISR) in plant cells that enhanced the plant defense (Benítez et al., 2004; Harman, 2006; Hermosa et al., 2013). Moreover, Barghouthi and Salman (2010) reported that bacteria may control parasitic weeds by interrupting signals required for radical elongation, haustorium formation, rhizotropism or attachment.

Table 3: Effects of Trichoderma spp. on growth of O. ramosa infested on chamomile plant during four months after transplanting (MAT)

\begin{tabular}{|c|c|c|c|c|c|c|c|c|c|c|c|c|}
\hline \multirow{2}{*}{$\begin{array}{l}\text { Parameters } \\
\text { MAT }\end{array}$} & \multicolumn{4}{|c|}{ Number of emerged spike } & \multicolumn{4}{|c|}{ Fresh weight (g) } & \multicolumn{4}{|c|}{ Dry weight (g) } \\
\hline & 1 & 2 & 3 & 4 & 1 & 2 & 3 & 4 & 1 & 2 & 3 & 4 \\
\hline $\begin{array}{l}\text { T. hamatum } \\
+ \text { O. ramosa }\end{array}$ & $0.0^{\mathrm{b}}$ & $0.0^{\mathrm{b}}$ & $0.0^{\mathrm{b}}$ & $0.8^{\mathrm{a}}$ & $0.0^{\mathrm{b}}$ & $0.0^{\mathrm{b}}$ & $0.0^{\mathrm{b}}$ & $0.1^{\mathrm{a}}$ & $0.0^{\mathrm{b}}$ & $0.0^{\mathrm{b}}$ & $0.0^{\mathrm{b}}$ & $0.1^{\mathrm{a}}$ \\
\hline $\begin{array}{l}\text { T. viride } \\
+ \text { O. ramosa }\end{array}$ & $0.0^{\mathrm{b}}$ & $0.0^{\mathrm{b}}$ & $0.0^{\mathrm{b}}$ & $4.0^{\mathrm{a}}$ & $0.0^{\mathrm{b}}$ & $0.0^{\mathrm{b}}$ & $0.0^{\mathrm{b}}$ & $2.2^{\mathrm{a}}$ & $0.0^{\mathrm{b}}$ & $0.0^{\mathrm{b}}$ & $0.0^{\mathrm{b}}$ & $0.4^{\mathrm{a}}$ \\
\hline $\begin{array}{l}\text { T.harzianum } \\
+ \text { O. ramosa }\end{array}$ & $0.0^{c}$ & $1.0^{\mathrm{b}}$ & $1.0^{\mathrm{b}}$ & $3.0^{\mathrm{a}}$ & $0.0^{c}$ & $2.3^{\mathrm{b}}$ & $2.6^{\mathrm{b}}$ & $3.4^{\mathrm{a}}$ & $0.0^{\mathrm{b}}$ & $0.4^{\mathrm{a}}$ & $0.7^{\mathrm{a}}$ & $0.9^{\mathrm{a}}$ \\
\hline $\begin{array}{l}\text { O. ramosa } \\
\text { alone }\end{array}$ & $2.3^{\mathrm{d}}$ & $4.5^{\mathrm{c}}$ & $7.5^{\mathrm{b}}$ & $16.5^{\mathrm{a}}$ & $0.5^{\mathrm{d}}$ & $4.5^{\mathrm{c}}$ & $18.9^{\mathrm{b}}$ & $36.3^{\mathrm{a}}$ & $0.1^{\mathrm{d}}$ & $0.7^{\mathrm{c}}$ & $4.9^{\mathrm{b}}$ & $5.3^{\mathrm{a}}$ \\
\hline
\end{tabular}

Values are given as means of three replicates. Means with the same letters in a column are not significantly different at $\mathrm{P}<0.05$.

\subsection{Effect of Trichoderma spp. on growth of chamomile plants infested with $O$. ramosa parasite}

The effect of Trichoderma spp. on growth of chamomile plants artificially infested with $O$. ramosa in pots are presented in Table 4. Infestation of chamomile plants with $O$. ramosa tended to cause significant reductions in various growth parameters of chamomile during 4 MAT (Table 4). Height of infested plants ranged between 18.5-58.8 cm corresponded with 21.5-74.5 cm for Orobanche non-infested plants. Adding Trichoderma fungi in the soil of $O$. ramosa infested plants improved plant height of chamomile plant, in most cases. $T$. viride produced the most enhancement effects on plant height (between 8.1-40.7\%), compared with Orobanche infested plants over the examined times. Although, application of $T$. harzianum did not produce any significant effects on plant height during the last two times points ( 3 and 4 MAT). As shown in Table 4, Orobanche infestation caused great reduction in chamomile biomass, as compared with non-infested plants. The reduction in fresh biomass over the examined periods was in the range $13.9-39.4 \%$ accompanied by $7.9-64.9 \%$ reduction in dry biomass. Presence of Trichoderma fungi in the pots of $O$. ramose infested plants induced great increase in fresh and dry weights of chamomile plants when compared with those of infested plants alone (Table 4). At $2^{\text {nd }}$ MAT, Trichoderma spp. increased fresh plant biomass between $44.5-100 \%$, as compared with infested plants alone and between 13.3-59.9\%, as compared with control (non-infested plants). Such increase was accompanied by increase in plant dry matter constituted between $62.1-79.3 \%$, relative to infested plants and $49.2-65.1 \%$, relative to healthy non-infested plants.

Fungi treatments continued to exert great enhancingin plant biomass of Orobanche infested plants over the examined period. At $4^{\text {th }}$ MAT, increases in fresh and dry weight of Trichoderma treated plants were in the range $59-90 \%$ and $67.6-112.2 \%$, respectively compared with infested plants. As shown in Table 4, Trichoderma spp. varied in their enhancing effects on fresh and dry weights of plants over the examined period. At $1^{\text {st }}$ MAT, T. hamatum produced the highest values of fresh and dry weight of chamomile plants (26.8 and $3.8 \mathrm{~g}$, respectively) as compare with infested plant alone (24.1 and $3.0 \mathrm{~g}$, respectively). At $2^{\text {nd }}$ MAT, $T$. harzianum produced the highest increase in fresh and dry weights of infested plants (100 and 79.4\%, respectively). Meanwhile, at the last two times points, $T$. viride was superior in enhancing fresh and dry plant biomass. It produced increases reached 85.1 and $91.2 \%$, respectively, relative to infested plants as well as 27.6 and $6.6 \%$ relative to non-infested plants. By the end of examined period, $T$. viride continued to produce the maximum increases in plant fresh and dry weights as compared with infested plants (89.7 and 112.1\%). The enhancement effects of different Trichoderma spp. on plant growth were previously observed in parsley (Barroso et al., 2019), coriander (Gebarowska et al., 2019) and Passifloracaerulea L. (Şesan et al., 2020). Moreover, an enhancement effect of Trichoderma in growth of Orobanche infested plants was previously observed by Hyder et al. 
(2017) and El-Dabaa and Abd-El-Khair (2020). Improving soil fertility by using beneficial microorganisms appeared to decrease Orobanche infestation and its suppressive effects on host growth (Elabaied et al.,2018).With accordance with our results, Khan and Parveen (2018) observed the superiority of $T$. viride in enhancing the growth and yield of coriander infected with Protomyces macrosporus.

Table 4: Effect of Trichoderma spp. on growth of chamomile plants infested with O.ramosa parasite during four months after transplanting (MAT)

\begin{tabular}{|c|c|c|c|c|c|c|c|c|c|c|c|c|}
\hline \multicolumn{13}{|c|}{ Plant growth } \\
\hline \multirow{2}{*}{$\begin{array}{l}\text { Parameters } \\
\text { MAT }\end{array}$} & \multicolumn{4}{|c|}{ Height (cm) } & \multicolumn{4}{|c|}{ Fresh weight (g) } & \multicolumn{4}{|c|}{ Dry weight (g) } \\
\hline & 1 & 2 & 3 & 4 & 1 & 2 & 3 & 4 & 1 & 2 & 3 & 4 \\
\hline $\begin{array}{l}\text { T. hamatum } \\
+ \text { O. ramosa }\end{array}$ & $20.0^{\mathrm{d}}$ & $32.5^{\mathrm{c}}$ & $48.3^{b}$ & $64.5^{\mathrm{a}}$ & $26.8^{\mathrm{d}}$ & $50.9^{\mathrm{c}}$ & $64.3^{\mathrm{b}}$ & $78.4^{\mathrm{a}}$ & $3.8^{\mathrm{d}}$ & $9.4^{\mathrm{c}}$ & $12.2^{\mathrm{b}}$ & $14.8^{\mathrm{a}}$ \\
\hline $\begin{array}{l}\text { T. viride } \\
+O \text {. ramosa }\end{array}$ & $22.5^{\mathrm{d}}$ & $33.5^{\mathrm{c}}$ & $58.1^{\mathrm{b}}$ & $69.1^{\mathrm{a}}$ & $21.1^{\mathrm{d}}$ & $50.3^{\mathrm{c}}$ & $76.8^{\mathrm{b}}$ & $93.5^{\mathrm{a}}$ & $3.0^{\mathrm{d}}$ & $9.5^{\mathrm{c}}$ & $13.0^{\mathrm{b}}$ & $15.7^{\mathrm{a}}$ \\
\hline $\begin{array}{l}\text { T. harzianum } \\
+O . \text { ramosa }\end{array}$ & $20.3^{\mathrm{d}}$ & $27.3^{\mathrm{c}}$ & $40.3^{b}$ & $59.0^{\mathrm{a}}$ & $22.3^{\mathrm{b}}$ & $71.0^{\mathrm{a}}$ & $73.6^{\mathrm{a}}$ & $79.6^{\mathrm{a}}$ & $3.4^{\mathrm{b}}$ & $10.4^{\mathrm{a}}$ & $12.1^{\mathrm{a}}$ & $12.4^{\mathrm{a}}$ \\
\hline $\begin{array}{l}\text { O. ramosa } \\
\text { Only }\end{array}$ & $18.5^{\mathrm{d}}$ & $31.0^{\mathrm{c}}$ & $41.3^{b}$ & $58.8^{\mathrm{a}}$ & $24.1^{\mathrm{c}}$ & $34.8^{\mathrm{b}}$ & $41.5^{\mathrm{b}}$ & $49.3^{\mathrm{a}}$ & $3.0^{\mathrm{c}}$ & $5.8^{\mathrm{b}}$ & $6.8^{\mathrm{b}}$ & $7.4^{\mathrm{a}}$ \\
\hline $\begin{array}{l}\text { Control } \\
\text { (untreated } \\
\text { plants) }\end{array}$ & $21.5^{\mathrm{d}}$ & $29.8^{c}$ & $55.8^{\mathrm{b}}$ & $74.5^{\mathrm{a}}$ & $28.0^{\mathrm{d}}$ & $44.4^{\mathrm{c}}$ & $60.2^{\mathrm{b}}$ & $81.4^{\mathrm{a}}$ & $4.5^{\mathrm{d}}$ & $6.3^{c}$ & $12.2^{\mathrm{b}}$ & $21.1^{\mathrm{a}}$ \\
\hline \multicolumn{13}{|c|}{ Root growth } \\
\hline \multicolumn{3}{|l|}{ Parameters } & \multicolumn{5}{|c|}{ Fresh weight (g) } & \multicolumn{5}{|c|}{ Dry weight (g) } \\
\hline \multicolumn{3}{|l|}{ MAT } & 1 & 2 & \multicolumn{2}{|c|}{3} & 4 & 1 & \multicolumn{2}{|c|}{2} & 3 & 4 \\
\hline \multicolumn{3}{|c|}{ T. hamatum $+O$. ramosa } & $4.6^{\mathrm{d}}$ & $8.3^{\mathrm{c}}$ & \multicolumn{2}{|c|}{$12.2^{\mathrm{b}}$} & $15.4^{\mathrm{a}}$ & $0.7^{\mathrm{d}}$ & \multicolumn{2}{|c|}{$1.3^{\mathrm{c}}$} & $2.2^{\mathrm{b}}$ & $2.7^{\mathrm{a}}$ \\
\hline \multicolumn{3}{|c|}{ T. viride $+O$. ramosa } & $4.2^{\mathrm{d}}$ & $13.0^{\mathrm{c}}$ & \multicolumn{2}{|c|}{$18.7^{\mathrm{b}}$} & $24.4^{\mathrm{a}}$ & $0.7^{\mathrm{d}}$ & \multicolumn{2}{|c|}{$1.9^{\mathrm{c}}$} & $2.8^{\mathrm{b}}$ & $3.7^{\mathrm{a}}$ \\
\hline \multicolumn{3}{|c|}{ T. harzianum+O. ramosa } & $5.4^{\mathrm{c}}$ & $15.2^{\mathrm{b}}$ & \multicolumn{2}{|c|}{$15.5^{\mathrm{b}}$} & $20.5^{\mathrm{a}}$ & $0.8^{\mathrm{c}}$ & \multicolumn{2}{|c|}{$2.4^{\mathrm{a}}$} & $2.4^{\mathrm{b}}$ & $2.7^{\mathrm{b}}$ \\
\hline \multicolumn{3}{|c|}{ O. ramose alone } & $4.0^{\mathrm{b}}$ & $6.1^{\mathrm{c}}$ & \multicolumn{2}{|c|}{$9.2^{\mathrm{c}}$} & $9.9^{\mathrm{d}}$ & $0.4^{\mathrm{b}}$ & \multicolumn{2}{|c|}{$0.7^{\mathrm{c}}$} & $1.0^{\mathrm{d}}$ & $1.4^{\mathrm{c}}$ \\
\hline \multicolumn{3}{|c|}{ Control (untreated plants) } & $4.1^{\mathrm{d}}$ & $5.9^{\mathrm{c}}$ & \multicolumn{2}{|c|}{$9.9^{b}$} & $12.5^{\mathrm{a}}$ & $0.4^{\mathrm{c}}$ & \multicolumn{2}{|c|}{$0.7^{\mathrm{b}}$} & $1.4^{\mathrm{a}}$ & $1.6^{\mathrm{a}}$ \\
\hline
\end{tabular}

Values are given as means of three replicates. Means with the same letters in a column are not significantly differentat $\mathrm{P}<0.05$.

In conclusion, the obtained results revealed that adding of Trichoderma spp.to the soil successfully reduced both infection and intensity of attack with $O$. ramosa on chamomile and enhanced the host growth. So, application of Trichoderma fungi may be provide ecofriendly strategy for crop disease management and can be a useful tool in sustainable modern agricultural practices and economically feasible.

\section{References}

Abdel-Kader, M.M., and El-Mougy, Nehal, S., 2002. Evaluation of different approaches of mycoherbicidal application for controlling Orobanche crenata in pea field. Egypt. J. Phytopathol. , 29: 69-82.

Abdel-Kader, M.M., and El-Mougy, Nehal, S., 2007. Applicable control measure against Orobanche ramosa in tomato plants. Australasian Plant Pathol., 36: 160-164.

Abdel-Kader, M.M., and El-Mougy,Nehal, S., 2009. Prospects of mycoherbicides for control of broomrapes (Orobanche spp.) in Egypt. J. Plant Protec. Res., 49(1):63-75.

Al-Wakeel, S., H. Moubasher, M.M. Gabr, and M.M.Y. Madany, 2013. Induced systemic resistance: an innovative control method to manage branched broomrape (Orobanche ramose L.) in tomato. IUFS J. Biol., 72(1):9-21.

Amsellem, Z., Y. Kleifeld, Z. Kereny, L. Hornok, Y. Goldwasser, and J. Gresse, 2001. Isolation, identification and activity of mycoherbicidal pathogens from juvenile broomrape plants. Biol. Control, 21: 274-284. 
Barghouthi, S., and M. Salman, 2010. Bacterial inhibition of Orobanche aegyptiaca and Orobanche cernua radical elongation. Biocontrol Sci.Technol., 20(4): 423-435.

Barroso, F.M., P.H.P. Costa-Muniz, M.D. Milan, and W. Silva Dos Santos, 2019. Growth promotion of parsley (Petroselinum crispum L.) using commercial strains of Trichoderma spp. J. Agric. Sci., 11(4):493-499.

Benitez, T., A.M. Rincon, M.C. Limon, and A.C. Codon, 2004. Biocontrol mechanisms of Trichoderma strains. Int. Microbiol., 7: 249-260.

Boari, A., and M. Vurro, 2014. Evaluation of Fusarium spp. and other fungi as biological control agents of broomrape (Orobanche ramosa). Biological Control, (2):212-219.

Elabaied, E.M., A.M.E. Rugheim, M.M. Hassan, M.M. Ahmed, M.A. Yahia, and R.A. Abakeer, 2018. Influence of bacteria on Orobanche crenata seed bank size, incidence and Vicia faba L. performance. Am.-Eurasian J. Sustain. Agric., 11(4):30-39

El-Dabaa, M.A.T., and H. Abd-Elkhair, 2020. Applications of plant growth promoting bacteria and Trichoderma spp. for controlling Orobanche crenata in faba bean. Bull. NRC., 44:4.

El-Nagdi, Wafaa, M.A., M.M.A. Youssef, H. Abd El-Khair, and M.M.M. Abd-Elgawad, 2019. Effect of certain organic amendments and Trichoderma species on the root-knot nematode, Meloidogyneincognita, infecting pea (Pisum sativum L.) plants. J.Biol. Pest. Control, 29:75.

Fernandez-Aparicio M., F. Flores, and D. Rubiales, 2016. The effect of Orobanche crenata infection severity in faba bean, field pea, and grass pea productivity. Front. Plant Sci., 7, Article 1409.

Gebarowska E., M. Pytlarz-Kozicka, J. No“Fer, J. Lyczko, M. Adamski, and H.A. Szumny, 2019. The effect of Trichoderma spp. on the composition of volatile secondary metabolites and biometric parameters of coriander (Coriandrum sativum L.).J. Food Quality, 2019, Article 5687032.

Habimana, S., A. Nduwumuremyi, and R.J.D. Chinama, 2014. Management of Orobanche in field crops- Areview. J. Soil Sci. Plant Nut., 14(1): 43-62.

Harman, G.E., 2006. Overview of mechanisms and uses of Trichoderma spp. Phytopathol., 96:190-194.

Hassan, E.A., S.S. El-Akkad, S.M. Mostafa, and M.El-Awadi, 2004. Histo-chemical aspects of penetration and vascular connection of broomrape haustoria in the host root and possible implication of phenylpropanoids. Int. J. Agric. Biol., 6(3): 430- 434.

Hermosa, R., M.B. Rubio, R.E. Cardoza, C. Nicolas, E. Monte, and S. Gutierrez, 2013. The contribution of Trichoderma to balancing the costs of plant growth and defense. Int. Microbiol., 16:69-80.

Hibberd, J., W. Quick, M. Press, and J. Scholes, 1998. Can source-sink relations explain responses of tobacco to infection by the root holoparasitic angiosperm Orobanche cernua? Plant Cell Environ. 21: 333-340.

Hyder, S., M. Inam-Ul-Hag, S. Bibi, A.H. Malik, S. Ghuffar, S. Iqbal, 2017. Novel potentialof Trichoderma spp. as biocontrol agent. J.Entomol. Zool. Stud., 5(4):214-222

Khan, M.R., and G. Parveen, 2018. Supplementing biocontrol agents with botanicals improved growth and yield of coriander (Coriandrum sativum L.) infected with Protomyces macrosporus Unger. Cur.Plant Biol., 15: 44-50.

Kuang, W., C. Wang, W. Mao, 2016. Screening and evaluation of herbicidal metabolites produced by Trichoderma spp. African J.Microbiol. Res., 10(24): 866-872.

Mauromicale, G., A.L. Monaco, and A.M. Longo, 2008. Effect of branched broomrape (Orobanche ramosa) infection on the growth and photosynthesis of tomato. Weed Sci., 56: 574-581.

Mustafa, A., M. Vaveed, Q. Saeed, M.N. Ashraf, A. Hussain, T. Abbas, M. Kamran, N. Nan-Sun, and X. Minggang, 2019. Application potentials of plant growth promoting rhizobacteria and fungi as an alternative to conventional weed control methods. 10.5772/intechopen. 863521(Chapter 16), doi: 10.5772/intechopen. 86339.

Nawar, Lobna, S., and A.F. Sahab, 2011. Evaluation of compost fortified with Trichoderma spp. isolates as biological agents against broomrape of chamomile herbs. Nature Sci., 9(8):229-236.

Punia, S.S., 2014. Biology and control measures of Orobanche. Indian J. Weed Sci., 46(1): 36-51.

Sesan, T.E., A.O. Oancea, L.M. Stefan, V.S. Manoiu, M. Ghiurea, I. Raut, D.C. Aruxandei, A. Toma, S.S. Savin, A.F. Bira, C.M. Pomohaci, and F. Oancea, 2020. Effects of foliar treatment with a Trichoderma plant biostimulant consortium on Passiflora caerulea L. yield and quality. Microorganisms, 8(1): 123.

Snedecor, G.W., and W.G. Cochran, 1999. Statistical Methods, $5^{\text {th }}$ ed. Ames (IA): Iowa State Univ. Press., 593. 
Westwood, J.H., 2000.Characterization of the Orobanche-Arabidopsis system for studying parasitehost interactions. Weed Sci., 48: 742-748.

Yahia M.A., M.M. Hassan, M.A.M. Elamien, N.K. Abdalla, A.M.E. Rugheim, R.H. Elsalahi, R.R.M. Abusin, R.A. Abakeer, M.M. Ahmed, A.G. Osman, M.E. Abelgani, and A.E. Babiker, 2018. Laboratory and field studies of Trichoderma harzianum, bacterial strains and imazethapyr on Orobanche crenata Forsk infesting Vicia faba. Asian J. Agric. Food Sci., 6(6).https://doi.org/10. 24203/ajafs.v6i6.5621. 